\title{
Prospective study on the expression of cancer testis genes and antibody responses in 100 consecutive patients with primary breast cancer
}

\author{
Axel Mischo' ${ }^{1}$, Boris Kubuschok ${ }^{1}$, Kubilay Ertan², Klaus-Dieter Preuss ${ }^{1}$, Bernd Romeike ${ }^{3}$, Evi Regitz ${ }^{1}$, Claudia Schormann ${ }^{1}$, \\ Diederik de Bruijn ${ }^{4}$, Andreas Wadle ${ }^{1}$, Frank Neumann ${ }^{1}$, Werner Schmidt ${ }^{3}$, Christoph Renner ${ }^{1}$ and Michael Pfreundschuh $^{1 *}$ \\ ${ }^{1}$ Department of Internal Medicine I, University of Saarland Medical School, Homburg/Saar, Germany \\ ${ }^{2}$ Obstetrics and Gynecology, University of Saarland Medical School, Homburg/Saar, Germany \\ ${ }^{3}$ Neuropathology, University of Saarland Medical School, Homburg/Saar, Germany \\ ${ }^{4}$ Department of Human Genetics, Radboud University Medical Center Nijmegen, Nijmegen, the Netherlands
}

\begin{abstract}
To determine the expression of cancer testis (CT) genes and antibody responses in a nonselected population of patients with primary breast cancer, we investigated the composite expression of 11 CT genes by RT-PCR in fresh biopsies of 100 consecutive cases of primary breast carcinoma and by immunohistology in selected RT-PCR-positive cases. Antibody responses against 7 CT antigens were analyzed using recombinant antigen expression on yeast surface. In 98 evaluable cases, $S C P-1$ and $S S X-4$ were expressed most frequently (both 65\%), followed by HOM-TES-85/CT-8 (47\%), GAGE (26\%), SSX-1 (20\%), NY-ESO-1 (13\%), MAGE-3 (11\%), SSX-2 (8\%), CT-10 (7\%), MAGE-4 (4\%) and CT-7 (1\%). One CT gene was expressed by $90 \%$ of the cases; $79 \%$ expressed $\geq 2,48 \%$ $\geq 3,29 \% \geq 4,12 \% \geq 5,6 \% \geq 6,3 \% \geq 7,2 \% \geq 8$ and one case coexpressed 9 antigens. Of 100 serum samples screened for CT antigen-specific antibodies, antibodies against $N Y$-ESO-1 were detected in 4 patients, against $S C P-1$ in 6 patients and against $S S X-2$ in 1 patient, while no antibodies were detected against $M A G E-3, C T-7$ and $C T-10$. Expression of CT genes or antibody responses was not correlated with clinical parameters (menopausal status, tumor size, nodal involvement, grading, histology and estrogen receptor status) or the demonstration of $\mathrm{CT}$ gene expression at the protein level, by immunohistology. Our results show that breast carcinomas are among the tumors with the most frequent expression of $\mathrm{CT}$ antigens, rendering many patients potential candidates for vaccine trials.

(C) 2005 Wiley-Liss, Inc.
\end{abstract}

Key words: breast cancer; cancer testis antigen; tumor rejection antigen; MAGE; GAGE; SSX; NY-ESO-1; SCP-1; specific immunotherapy; cancer vaccine

Breast cancer is one of the most common malignancies in women and second in cancers causing death among women in the United States, where over 40,000 patients die each year of the disease. ${ }^{1}$ Despite effective adjuvant therapy after primary surgery, ${ }^{2}$ a considerable proportion of patients with limited-stage disease develop metastatic disease. Even though the median survival of patients with metastatic breast cancer can be prolonged by effective hormonal ${ }^{3}$ and chemotherapeutic ${ }^{4}$ agents as well as combinations of chemotherapy with the anti-her-2/neu antibody trastuzumab, ${ }^{5}$ metastatic disease is eventually fatal. An attractive approach to reduce the rate of failures after primary treatment of breast cancer could be immunotherapeutic strategies, which should be most efficient in the state of minimal residual disease after primary treatment of patients with limited-stage disease.

A prerequisite for the development of tumor-specific immunotherapeutic strategies is the existence and identification of tumor antigens, i.e., genes that are either exclusively or preferentially expressed in malignant compared to normal tissues. In breast cancer, only few tumor antigens are known, and most are overexpressed in tumor cells but will also be found at a certain level in normal human cells, e.g., CEA, CA15-3, Her-2/neu, MUC-1. ${ }^{6,7}$ Expression of these genes in normal tissue limits their use as targets for specific immunotherapy. In contrast to the overexpressed antigens, the so-called shared tumor antigens are expressed only by a variety of malignant tumors, not by normal tissues except for the germ cells in testis. Due to this peculiar expression profile, the terms $C T^{8}$ and $C G^{9}$ antigen have been coined for them. An impor- tant point concerning the therapeutic use of CT antigens is that vaccines targeting them will not affect germ cells because they lack expression of the MHC molecules that are necessary for the presentation of the respective antigenic peptides. The group of CT antigens includes the CTL-reactive MAGE, ${ }^{10} B A G E^{11}$ and $G A G E^{12}$ families, as well as HOM-MEL-4O/SSX-2, ${ }^{13}$ the other SSX family members, ${ }^{14} N Y$-ESO- $1,{ }^{8}$ HOM-TES-14/SCP-1, ${ }^{15}$ $C T-7,{ }^{16} H O M-T E S-85 / C T-8^{17}$ and $C T-10,{ }^{8}$ all of which have been defined using SEREX. ${ }^{18}$ Analysis of the expression pattern of the CT genes revealed that some of them are also expressed in breast cancer. ${ }^{19,20}$ However, little is known about the composite expression of CT genes in primary breast cancer, and no data are available on the incidence of antibodies against these antigens in breast cancer. Our study of a large panel of CT genes in primary breast cancer shows that these tumors frequently express a selected spectrum of CT genes, providing the molecular basis for the development of CT antigen-based vaccine strategies.

\section{Material and methods \\ Tissues and cell lines}

The study was approved by the local ethics review board (Ethikkommission der Ärztekammer des Saarlandes) and performed according to the Declaration of Helsinki. Recombinant DNA work was done with official permission and in accordance with the rules of the state government of Saarland. After informed consent, tumor and serum samples were obtained from 100 patients with operable breast cancer upon the primary definitive operation (mastectomy, 36 cases; lumpectomy, 59 cases; reductive tumor surgery, 5 cases) at the Department of Gynecology, University of Saarland Medical School, between June 2001 and May 2002. Biopsy samples were snap-frozen within $1 \mathrm{hr}$ after excision. Tumor stage and grading were determined according to the UICC. ${ }^{21}$ Breast cancer tissue was divided in 2 parts. One part was fixed in formalin and embedded in paraffin for conventional histopathologic staining (hematoxylin and eosin) and immunohistochemistry. The other part was snap-frozen in liquid nitrogen and microscopically checked for the presence of neoplastic tissue and the amount of contaminating normal breast tissue in cryostat sec-

Abbreviations: CG, cancer germline; CT cancer testis; CTL, cytotoxic $\mathrm{T}$ lymphocyte; MAb, monoclonal antibody; OD, optical density; RAYS, recombinant antigen expression on yeast surface; SEREX, serologic identification of antigens by recombinant expression screening; TBS, TRIS-buffered saline.

Grant sponsor: Deutsche Forschungsgemeinschaft; Grant number: PF135/7-1; Grant sponsor: Deutsche Krebshilfe, Ludwig Institute for Cancer Research and Cancer Research Institute.

The first 2 authors contributed equally to this work

* Correspondence to: Medizinische Klinik I, Universitätskliniken des Saarlandes, D-66421 Homburg/Saar, Germany. Fax: +49-6841-1623101. E-mail: inmpfr@uniklinik-saarland.de

Received 10 March 2005; Accepted after revision 4 May 2005

DOI 10.1002/ijc.21352

Published online 10 August 2005 in Wiley InterScience (www.interscience. wiley.com). 
tions before use for RT-PCR. Normal tissues were collected from breast-reduction operations performed for cosmetic reasons.

\section{$R T-P C R$}

Total cellular RNA was extracted from frozen tissue specimens of 100 fresh breast cancer samples, 4 normal breast tissues (obtained from breast-reduction operations) and other normal tissues (see Results) using guanidinium-isothiocyanate for denaturation followed by an acidic phenol extraction and isopropanol precipitation. ${ }^{18}$ Total RNA $(4 \mu \mathrm{g})$ was primed with an oligo(dT)18 oligonucleotide and reverse-transcribed with Superscript II (Life Technologies, Eggenstein, Germany) according to the manufacturer's instructions. The cDNA obtained was tested for integrity by amplification of $\beta$-actin and p53 transcripts in a 35-cycle PCR, as described elsewhere. ${ }^{22}$ For PCR analysis of the expression of individual CT gene transcripts, first-strand cDNA was amplified with transcript-specific oligonucleotides $(10 \mu \mathrm{mol})$ using 1 unit of AmpliTaq Gold (Perkin Elmer, Weiterstadt, Germany), $10 \mathrm{nmol}$ of each deoxynucleotide triphosphate (dATP, dTTP, dCTP, dGTP) and $1.67 \mathrm{mM} \mathrm{MgCl}$ in a $30 \mu \mathrm{l}$ reaction. The primers (MWG Biotech, Ebersberg, Germany) for the respective CT genes have been reported previously ${ }^{20,23,24}$ and were as follows: $S S X-15^{\prime}\left(5^{\prime}\right.$-CTA AAG CAT CAG AGA AGA GAA GC) and $S S X-13^{\prime}$ (5'-AGA TCT CTT ATT AAT CTT CTC AGA AA), annealing temperature $56^{\circ} \mathrm{C} ; S S X-25^{\prime}\left(5^{\prime}\right.$-GTG CTC AAA TAC CAG AGA AGA TC) and $S S X-23^{\prime}$ (5'-TTT TGG GTC CAG ATC TCT CGT G), annealing temperature $67^{\circ} \mathrm{C}$; $S S X-45^{\prime}\left(5^{\prime}\right.$-AAA TCG TCT ATG TGT ATA TGA AGC T) and SSX-4 $3^{\prime}$ (5'-GGG TCG CTG ATC TCT TCA TAA AC) primers, annealing temperature $60^{\circ} \mathrm{C} ; S C P-1$ $5^{\prime}$ (5'-GTA CAG CAG AAA GCA AGC AAC TGA ATG) and $S C P-1 \quad 3^{\prime}\left(5^{\prime}\right.$-GAA GGA ACT GCT TTA GAA TCC AAT TTC C) primers, annealing temperature $60^{\circ} \mathrm{C} ; \mathrm{HOM}-\mathrm{TES}-85 / \mathrm{CT}-85^{\prime}$ (5'-GGA GAG GCT ACT CAA GAT GCA GAA GC) and $\mathrm{HOM}$ $T E S-85 / C T-83^{\prime}$ (5'-CTG AGT GAC TAT GAG ATC TCT CTG) primers, annealing temperature $64^{\circ} \mathrm{C} ; N Y$-ESO-la $5^{\prime}$ (5'-AGT TCT ACC TCG CCA TGC CT-3') and $3^{\prime}\left(5^{\prime}-\right.$ TCC TCC TCC AGC GAC AAA CAA- $\left.3^{\prime}\right) ; N Y$-ESO- $1 b 5^{\prime}\left(5^{\prime}\right.$-ATG GAT GCT GCA GAT GCG G-3') and $3^{\prime}$ ( $5^{\prime}$-GCTTAGCGCCTCTGCCCTG$\left.3^{\prime}\right)$, annealing temperature $60^{\circ} \mathrm{C} ; M A G E-35^{\prime}\left(5^{\prime}\right.$-TGG AGG ACC AGA GGC CCC C) and MAGE-3 $3^{\prime}\left(5^{\prime}\right.$-GGA CGA TTA TCA GGA GGC CTG C), annealing temperature $62^{\circ} \mathrm{C} ; M A G E-45^{\prime}\left(5^{\prime}-\right.$ GAG CAG ACA GGC CAA CCG) and MAGE-4 $3^{\prime}$ (3'-AAG GAC TCT GCG TCA GGC), annealing temperature $67^{\circ} \mathrm{C}$; GAGE $5^{\prime}$ (5'-AGA CGC TAC GTA GAG CCT) and GAGE $3^{\prime}$ (5'-CCA TCA GGA CCA TCT TCA) primers, annealing temperature $63^{\circ} \mathrm{C}$; $C T-75^{\prime}$ (5'-CGG AGG GAG GAG ACT TA), sense, and $C T-73^{\prime}$ (5'-TTA AGG TGG TGC TCT AGG), antisense, annealing temperature $61^{\circ} \mathrm{C} ; C T-105^{\prime}\left(5^{\prime}\right.$-CGG ATC GAA GGC ATT TGT GAG- $\left.3^{\prime}\right)$ and $3^{\prime}\left(5^{\prime}\right.$-GTG AAC TCA CGG GCT CTC TTG AG- $\left.3^{\prime}\right)$, annealing temperature $55^{\circ} \mathrm{C}$.

Amplification was performed in a TRIO-Thermoblock (Biometra, Gottingen, Germany). After 12 min activation of AmpliTaq Gold polymerase at $94^{\circ} \mathrm{C}$ for hot-start induction, 35 cycles of PCR were performed with $1 \mathrm{~min}$ at the respective annealing temperature as indicated above, $2 \mathrm{~min}$ at $72^{\circ} \mathrm{C}$ and $1 \mathrm{~min}$ at $94^{\circ} \mathrm{C}$, with a final elongation step at $72^{\circ} \mathrm{C}$ for $8 \mathrm{~min}$. A $15 \mu \mathrm{l}$ aliquot of each reaction was size-fractionated on a $2 \%$ agarose gel, visualized by ethidium bromide staining and assessed for products of the expected size.

\section{Detection of antibodies against CT antigens}

Patient sera were studied for antibodies against CT antigens by flow cytometry using yeast transformed to express the recombinant antigen on the surface. RAYS was performed as described previously. ${ }^{25}$ The pYD1 plasmid was part of the pYD1 yeast display vector kit from Invitrogen (Leiden, Netherlands). cDNA coding for the analyzed CT antigens was amplified by PCR from phage supernatant. Primers (MWG Biotech) were as follows: NY-ESO-1 5' (5'-GGG GAA TTC CAG GCC GAA GGC CGG GGG CAC) and NY-ESO-1 3' (5'-GGG CTC GAG TTA GCG CCT CTG CCC TGA GGG);
$S S X-2$ and $S S X-45^{\prime}\left(5^{\prime}\right.$-GGG GGG GAA TTC AAC GGA GAC GAC GCC TTT G) and SSX-2 and SSX-4 $3^{\prime}$ (5'-CTA CTC GAG TTA CTC GTC ATC TTC CTC AGG GTC); MAGE-A3 $5^{\prime}$ (5'-GGG GGC AAT TGC CTC TTG AGC AGA GGA GTC AGC AC) and $M A G E-A 33^{\prime}\left(5^{\prime}\right.$-GGG GCT CGA GTC ATC CTT CCC CCT CTC TCA AAA CC); $C T-75^{\prime}$ (5'-CCA AAG AAT TCG GCA CAA TTG CCT CAG GGG) and $C T-73^{\prime}\left(5^{\prime}\right.$-GGG CTC GAG TCA CTC AGA AGA GAA GCT GGG GAA); $C T-105^{\prime}$ (5'-GCA GAG TGG CCA TTA TGG CCC CCT CCC GTT CCA GGC GTT CCA TTC) and $C T-103^{\prime}\left(5^{\prime}\right.$-GCG GCC GAC ATG TTT TTT CCC TCA CTC AGA AAA GGA GAC GTT GCT GG); $S C P-1$ fragment 1 (bp 1870) $5^{\prime}$ (5'-GAT AGG ATC CAT GGA AAA GCA AAA GCC CTT TGC) and $S C P-1$ fragment $13^{\prime}\left(5^{\prime}\right.$-ACT CGA GTA CCT GCT TTT CCT TGT CAT TTA TTT CC); $S C P-1$ fragments $1 / 2$ (bp 1-1623) $5^{\prime}$ (5'-GAT AGG ATC CAT GGA AAA GCA AAA GCC CTT TGC) and $S C P-1$ fragments $1 / 23^{\prime}\left(5^{\prime}\right.$-GAT ACT CGA GGT GTG AAG TTA ATT CAG TAT TCT TAA GC); $S C P-1$ fragment 2 (bp 8071623) $5^{\prime}\left(5^{\prime}\right.$-TAG GAT CCG TGC AAG CTG AGA ATT CCA GAC TGG) and SCP- 1 fragment $23^{\prime}\left(5^{\prime}\right.$-ACT CGA GGT GTG AAG TTA ATT CAG TAT TCT TAA GC); $S C P-1$ fragments $2 / 3$ (bp 807-2415) 5' (5'-TAG GAT CCG TGC AAG CTG AGA ATT CCA GAC TGG) and $S C P-1$ fragments $2 / 33^{\prime}\left(5^{\prime}\right.$-ACT CGA GTT CTT TTG CCT CTC TTT TGA GTT TTT CC); $S C P-1$ fragments 3/4 (bp 1589-2995) 5' (5'-TAG GAT CCA CAA GTG AAC AGT ATT ATT CAA AAG AG) and $S C P-1$ fragments 3/4 $3^{\prime}\left(5^{\prime}\right.$-TAC TCG AGA ACA AAT AAC TTT TCA GCT TCT TTT AG).

Because of its size, $S C P-1$ had to be divided into several fragments, which were cloned into the BamH1/XhoI sites of pYD1. $N Y$-ESO-1-, MAGE-A3, SSX-2 and SSX-4 inserts were cloned into the EcoRI/XhoI sites of pYD1. $C T-7$ and $C T-10$ were inserted by homologous recombination. $S S X-2$ and $S S X-4$ primers are identical because of identical $5^{\prime}$ and $3^{\prime}$ cDNA sequence of $S S X-2$ and $S S X-4$, respectively. All constructs were checked by sequencing. The plasmids pYD1, pYD1-NY-ESO-1, pYD1-SSX-2, pYD1SSX4, pYD1-CT-7, pYD1-CT10 and pYD1-Mage-A3 as well as the plasmids containing the 5 fragments of $S C P-I$ were introduced into Saccharomyces cerevisiae EBY100 using a commercially available transformation kit (EasyComp, Invitrogen) according to the manufacturer's recommendations. Thereafter, yeasts were spread on MD-Leu plates $(0.67 \%$ yeast nitrogen base, $2 \%$ dextrose, $0.01 \%$ leucine, $1.5 \%$ agar) for the selection of transformed clones. Colonies were picked and cultured [YPD/CAA-Glu: $1 \%$ yeast extract, $2 \%$ polypeptone, $2 \%$ dextrose; YNB/CAA-Glu: $2 \%$ dextrose, $0.67 \%$ yeast nitrogen base, $0.5 \%$ Casamino acids (Difco, Detroit, MI)] with constant agitation to an approximate OD $(600 \mathrm{~nm})$ of $4\left(30^{\circ} \mathrm{C}, 4 \mathrm{hr}\right)$. To induce surface protein expression, yeasts were pelleted by centrifugation, resuspended to an OD $(600 \mathrm{~nm})$ of 0.6 in $\mathrm{YNB} / \mathrm{CAA}-\mathrm{Gal}$ and grown with agitation for an additional $48 \mathrm{hr}\left(20^{\circ} \mathrm{C}\right)$.

For preabsorption, sera were diluted 1:50 in PBS and mixed with approximately $1 / 4$ volume of pelleted yeast containing the empty pYD1 vector. This preabsorption mix was agitated overnight at $4{ }^{\circ} \mathrm{C}$ to eliminate unspecific binding to yeast surface molecules. After pelleting, the supernatant was recovered and diluted with PBS to a final serum dilution of $1: 100$. Sodium azide $(0.05 \%$ $\mathrm{w} / \mathrm{v}$ ) was added for preservation.

Transformed and induced yeast cells were collected by centrifugation $(2,000 \mathrm{~g}, 5 \mathrm{~min})$ and washed with PBS. Yeasts containing pYD1 as a control and yeasts containing pYD1 with the respective antigenic inserts were incubated at room temperature with $100 \mu \mathrm{l}$ of preabsorbed serum (final dilution 1:100) for $30 \mathrm{~min}$ with occasional agitation. After washing with PBS (0.1\% Tween), secondary biotinylated antihuman IgG Fc- $\gamma$-specific serum (Dianova, Hamburg, Germany; dilution 1:200) was added and incubated for $30 \mathrm{~min}$ at room temperature with occasional agitation. Finally, Rphycoerythrin-conjugated streptavidin (Dianova) was added (dilution 1:200, room temperature, $15 \mathrm{~min}$ ) and washed twice with PBS $(0.1 \%$ Tween). Expression control for the cloned antigens was performed by detection of expressed HIS-tag using the specific biotinylated anti-penta HIS antibody (1:500; Qiagen, Hilden, 
TABLE I - PATIENT CHARACTERISTICS AND EXPRESSION OF CT ANTIGENS

\begin{tabular}{|c|c|c|}
\hline Characteristic & Number of patients & $\begin{array}{l}\text { Number of patients } \\
\text { with expression of a } \\
\text { CT gene mRNA }\end{array}$ \\
\hline Total & 98 & $88(90 \%)$ \\
\hline \multicolumn{3}{|l|}{ pT status } \\
\hline $\mathrm{pT}_{1-2}$ & $83^{1}$ & $76(91 \%)$ \\
\hline $\mathrm{pT}_{3-4}$ & 14 & $12(86 \%)$ \\
\hline \multicolumn{3}{|l|}{ pN status } \\
\hline $\mathrm{pN}_{0}$ & 50 & $44(88 \%)$ \\
\hline $\mathrm{pN}_{1}$ & 48 & $44(92 \%)$ \\
\hline \multicolumn{3}{|l|}{ Stage } \\
\hline 0/I/II & 84 & $76(91 \%)$ \\
\hline III/IV & 14 & $12(86 \%)$ \\
\hline \multicolumn{3}{|l|}{ Grading } \\
\hline Moderately & $30^{1}$ & $26(87 \%)$ \\
\hline Poor & 67 & $61(91 \%)$ \\
\hline \multicolumn{3}{|l|}{ Menopausal status } \\
\hline Premenopausal & 27 & $24(89 \%)$ \\
\hline Postmenopausal & 71 & $64(90 \%)$ \\
\hline \multicolumn{3}{|l|}{ Histology } \\
\hline Invasive ductal & 72 & $65(90 \%)$ \\
\hline Invasive lobular & 13 & $10(77 \%)$ \\
\hline Other $^{2}$ & 13 & $13(100 \%)$ \\
\hline
\end{tabular}

${ }^{1} \mathrm{No} \mathrm{T}$ stage and grading for one case with ductal carcinoma in situ. $-{ }^{2}$ See Results.

Germany) and R-phycoerythrin-conjugated streptavidin (dilution 1:200, $15 \mathrm{~min}$ incubation). Labeled yeast cell suspensions were analyzed by flow cytometry (FACScan; Becton Dickinson, Heidelberg, Germany). For each sample, 30,000 cells were collected. The ratio between the intensity of the signal measured on antigenexpressing and nonexpressing (pYD1) yeasts was calculated for each individual serum sample. A sample was considered to be positive if this ratio was $\geq 2$. All positive antibody reactivities were confirmed using the phage assay, as described before. ${ }^{13}$

\section{Immunohistochemistry}

Paraffin sections were deparaffinized in xylene and rehydrated in decreasing concentrations of ethanol. Following a rinse with distilled water, endogenous peroxidase was quenched with 3\% hydrogen peroxide in methanol. Antigen was retrieved by incubation in buffer (S2031; Dako-Cytomation, Glostrup, Denmark) at $90-95^{\circ} \mathrm{C}$ for $30 \mathrm{~min}$. Unspecific binding sites were blocked by incubation in $20 \%$ rabbit serum in TBS $(v / v)$ for $20 \mathrm{~min}$. For detection of $S C P-1$, sections were incubated for $30 \mathrm{~min}$ at $37^{\circ} \mathrm{C}$ with a previously determined optimal dilution of mouse anti-SCP-1 MAb MA $^{26}$ (SC554, IgG1; hybridoma supernatant diluted $1: 3$ in TBS, $1 \%$ BSA, 0.1\% Tween). For detection of SSX, sections were incubated overnight at $4^{\circ} \mathrm{C}$ with mouse anti-SSX MAb reacting with $S S X-2, S S X-3$ and SSX-4 but not $S S X-1$ (E3AS, IgG; hybridoma supernatant diluted 1:2 in TBS, 1\% BSA, 0.1\% Tween). ${ }^{27}$ After washing with TBS, slides were incubated with biotinylated rabbit antimouse immunoglobulin antibody (1:200 in TBS, 1\% BSA, 0. $1 \%$ Tween; E0413, Dako-Cytomation) for $15 \mathrm{~min}$ at $37^{\circ} \mathrm{C}$, washed and incubated with horseradish peroxidase-conjugated streptavidin complex $(1: 300$ in TBS, $1 \%$ BSA, 0,1\% Tween; P0397, Dako-Cytomation) for $15 \mathrm{~min}$ at $37^{\circ} \mathrm{C}$. Sections were sequentially washed. The color reaction was developed with diaminobenzidine in TRIS-HCl buffer (3468, Dako-Cytomation) and stabilized by saturated cupric sulfate for $2 \mathrm{~min}$. Slides were counterstained with Mayer's hematoxylin. Nonspecific staining of the primary antibody was assessed by substituting an isotype-matched mouse myeloma antibody against an irrelevant protein (MOPC-21, IgG1; Sigma, Deisenhofen, Germany). A consecutive section was stained by hematoxylin and eosin. Positive control sections of testis were included with each batch of staining.

\section{Results}

Study population and validity of the experimental approach

Expression of $11 \mathrm{CT}$ genes (SCP-1, MAGE-3, MAGE-4, GAGE, SSX-1, SSX-2, SSX-4, NY-ESO-1, CT-7, HOM-TES-85/CT-8 and $C T-10$ ) was analyzed in 100 samples of fresh biopsies from primary breast cancer. With the exception of one case, all specimens were proven to contain breast cancer tissue by routine histopathologic evaluation of hematoxylin and eosin-stained slides. Another sample was negative for $\mathrm{p} 53$ expression by RT-PCR and therefore considered not evaluable for the expression studies, leaving a total of 98 evaluable cases.

Intensities of PCR products were heterogeneous, and some specimens yielded only faint amplicon bands. These were scored positive only if the result could be reproduced by repeated RNA extraction and specific PCR from the same tumor specimen with clear bands. Cases with very low transcript levels in 2 experiments and negative in a third test were not regarded as positive.

Complete clinical and immunohistologic data on 98 patients treated by either breast-conserving surgery or mastectomy were available (Table I). Median age was 59 years, with $28 \%$ in preand $72 \%$ in postmenopause. According to the UICC classification, $54 \%$ of patients had stage II invasive breast cancer and $32 \%$ had stage I disease. Therefore, the majority of patients $(86 \%)$ suffered from early-stage invasive breast cancer (stages I and II), whereas $14 \%$ of patients were afflicted with locally advanced breast cancer (stage III). Histopathologic analysis demonstrated invasive ductal carcinoma in $73 \%$ of cases and invasive lobular carcinoma in $13 \%$. The remaining $14 \%$ were diagnosed as mucinous, medullary, tubular, intraductal, solid and cribriform carcinoma.

\section{Expression of individual CT gene mRNA in primary} breast cancer

None of the $11 \mathrm{CT}$ antigens studied was expressed in normal breast tissue $(n=4)$ or other normal tissues (bladder, brain, colon, kidney, liver, lung, lymph node, muscle, ovary, peripheral blood lymphocytes, prostate, rectum, skin, spleen, stomach, tonsil, uterus). In contrast, primary breast cancers frequently expressed one or more CT gene mRNA (Fig. 1). The most frequently expressed CT genes were HOM-TES-14/SCP-1 and SSX-4, which were both detected in $65 \%$ of cases, followed by HOM-TES-85/CT-8 (47\%), GAGE (26\%), SSX-1 (20\%), NY-ESO-1 (13\%), MAGE-3 (11\%), $S S X-2(8 \%), C T-10(7 \%), M A G E-4(4 \%)$ and $C T-7(1 \%)$.

\section{Coexpression of multiple CT gene mRNA in primary} breast cancer

Expression of at least one antigen was observed in 88 breast cancer samples, and 77 cases expressed more than one CT gene (Fig. 2). Three or more CT genes were expressed in 47 cases. Still more than one-quarter $(29 \%)$ expressed at least 4 CT genes, while 16 specimens expressed $\geq 5,6$ cases 6,3 cases $\geq 7,2$ cases $\geq 8$ and one coexpressed 9 antigens. There was no obvious correlation between the expression of different CT genes. While SCP-1 was the most frequently expressed CT gene, of the 88 tumors that expressed at least one CT gene, 25 were negative for $S C P-1$ and 6 did not express either of the 2 most frequently expressed genes, $S C P-1$ and $S S X-4$.

\section{Antibody reactivities against CT antigens in patients with primary breast cancer}

Sera from all of the 100 patients included in the study were obtained at the day of breast surgery and tested for the presence of antibodies against $7 \mathrm{CT}$ antigens together with the sera of 50 healthy controls using RAYS: $M A G E-3, S C P-1, S S X-2, S S X-4$, $N Y-E S O-1, C T-7$ and $C T-10$. No antibodies were detected in the sera of 50 healthy controls. Antibodies against NY-ESO-1 were detected in the serum of 4 patients, against $S C P-1$ in 6 and against $S S X-2$ in one patient; but no antibody reactivities were detected against $S S X-4, M A G E-3, C T-7$ and CT-10. Three of $12(25 \%)$ 


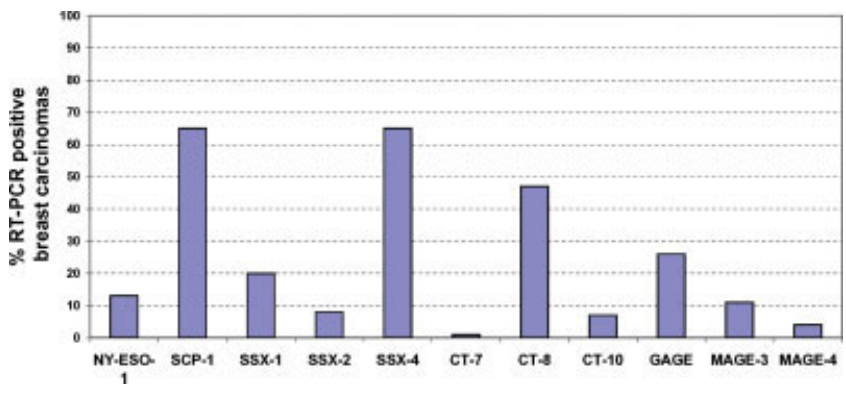

FIGURE 1 - Frequency of CT gene expression in primary breast carcinoma. The proportion of RT-PCR-positive cases is shown as a percentage of 98 evaluable breast carcinoma samples.

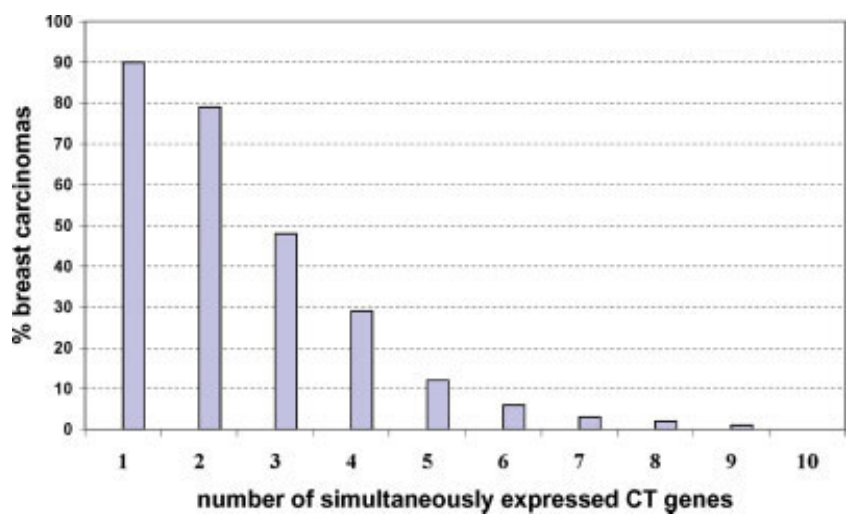

Figure 2 - Simultaneous expression of multiple CT antigens in primary breast cancer. The proportion of breast carcinomas expressing at least one and up to $10 \mathrm{CT}$ antigens is shown as a percentage of 98 samples.

patients with $N Y$-ESO-I-positive tumors had detectable anti- $N Y$ $E S O-1$ antibody levels; in the tumor of the fourth anti-NY-ESO-I antibody-positive patient, no $N Y-E S O$ antigen was detected on repeated RT-PCR and immunohistologic analyses. Of the 63 patients with $S C P$ - 1 -positive tumors, $6(10 \%)$ had anti-SCP- 1 antibody reactivity in their serum. The frequency of specific antibodies in the serum of patients with $S S X$-2-positive tumors was simi$\operatorname{lar}(1 / 8 \%$ or $12.5 \%)$.

\section{Expression of CT genes and correlation with clinicopathologic parameters}

Expression of each CT gene was correlated with the following 6 parameters: histology (ductal vs. lobular carcinoma); size of primary tumor (T1/2 vs. T3/4), presence or absence of lymph node involvement (N0 vs. N1), grade of differentiation (2 vs. 3), menopausal status (premenopausal vs. postmenopausal) and estrogen receptor status. $N Y-E S O-1$ was more often associated with lobular than with ductal carcinoma ( $p=0.04, \chi^{2}$ test), MAGE-3 was more often associated with larger primary tumors (T3,4; $p=0.015, \chi^{2}$ test) and $S C P-1$ expression was more often associated with nodular involvement $\left(p=0.03, \chi^{2}\right.$ test $)$ and estrogen receptor-negative tumors $\left(p=0.01, \chi^{2}\right.$ test). However, when adapted for multiple testing and a critical $p$ value $<0.0083$ (i.e., $0.05 / \mathrm{G}=0.083$ ), these correlations did not retain clinical significance.

\section{SSX and SCP-1 protein expression}

RT-PCR-positive breast carcinoma samples from which sufficient material was available were investigated for expression of the frequently expressed SSX and SCP-1 proteins by immunohistochemistry. Expression of SSX protein was found in 5 of 16 SSX
RT-PCR-positive tumor samples (31\%). The staining pattern varied from single positive cells to foci of positive cells distributed all over the tumor. As shown in Figure 3, positive cancer cells showed nuclear reactivity. Expression of SCP-1 antigen was demonstrated in 6 of 13 SCP-1 RT-PCR-positive tumor samples $(46 \%)$ and revealed up to $50 \%$ single positive tumor cells per sample (Fig. 4). CT antigen-positive tumors, as demonstrated by immunohistology, were found both in patients with and without antibody reactivity against the respective antigen in their serum. However, because the selection of tumors for immunohistology was solely based on the availability of sufficient biopsy material, there was a bias toward larger tumors analyzed for protein expression. Due to this fact and the small number of appropriate biopsies available, correlations of protein expression as demonstrated by immunohistology with any of the clinical parameters listed in Table I or the presence of antibodies in the serum of the respective patients could not be investigated.

\section{Discussion}

To date, no systematic survey of CT gene expression and antibody responses against $\mathrm{CT}$ antigens in breast cancer patients has been published. In our population of patients with early breast cancer, $N Y$-ESO-l was confirmed as the most autoimmunogenic CT antigen, with detectable antibody levels in one-quarter of patients with $N Y$-ESO-I-positive tumors. In contrast, the incidence of $S C P-1$ and $S S X-2$ antibodies in patients with tumors expressing the respective antigens was much lower, and antibodies against the other 4 CT antigens expressed by the tumors were not detected. The low incidence of antibodies to CT antigens in this population might be interpreted as support for the widespread assumption that the incidence of antibodies against CT antigens is lower in patients with early-stage carcinoma than in patients with a higher tumor load. However, this assumption is not based on solid ground because no systematic studies addressing this question have been published to date; rather, published reports are mostly anecdotal and, therefore, no firm conclusions as to the frequency of CT gene expression and antibody reactivity in the serum of patients with low vs. high tumor load can be drawn. We cannot exclude the possibility that CT antigen expression and antibody frequencies might be quite different in metastatic disease; however, there is no published study that prospectively compared $\mathrm{CT}$ antigen expression and antibody reactivity in limited-stage and metastatic disease. A previous smaller (and retrospective) study performed by our group in a different series of patients that also included patients with metastatic disease ${ }^{28}$ yielded frequencies of $S S X$ and $S C P-1$ expression and antibodies against these CT antigens that were quite similar to the ones reported here.

Antibodies against CT antigens were detected only in patients with tumors expressing the respective CT gene mRNA but not in patients with CT gene-negative tumors or healthy controls. The only exception to this was the detection of $N Y-E S O-1$ antibodies in the serum of one patient with an NY-ESO-I-negative tumor. This case was checked again for $N Y$-ESO-l expression by RTPCR using 2 different primer pairs, and $N Y-E S O-1$ negativity was confirmed. The presence of specific IgG antibodies in the absence of $N Y-E S O-1$ expression might be explained by a recent report, where $N Y$-ESO-l was found in $68 \%$ of fibroadenomas and fibrocystic disease cases. $^{29}$

The physiologic function of most CT genes is unknown, and their possible role in tumorigenesis can only be speculated. ${ }^{30,31}$ The CT gene with the most frequent expression in breast carcinoma was that coding for $H O M-T E S-14 / S C P-1$, which is involved in meiotic chromosome pairing. ${ }^{32} S C P-1$ is also frequently found $(30-50 \%)$ in other neoplasms, including gastrointestinal cancers like colorectal and gastric carcinomas, ${ }_{20}^{20}$ hepatocellular carcinomas, ${ }^{24}$ breast carcinomas, ${ }^{20}$ astrocytomas, ${ }^{26}$ lymphomas $^{33}$ and pancreatic carcinomas. ${ }^{23}$ The function of $S S X-4$, the other CT gene found in a significant proportion of breast carcinomas, is not known. Expression of the other CT genes investigated in our study 


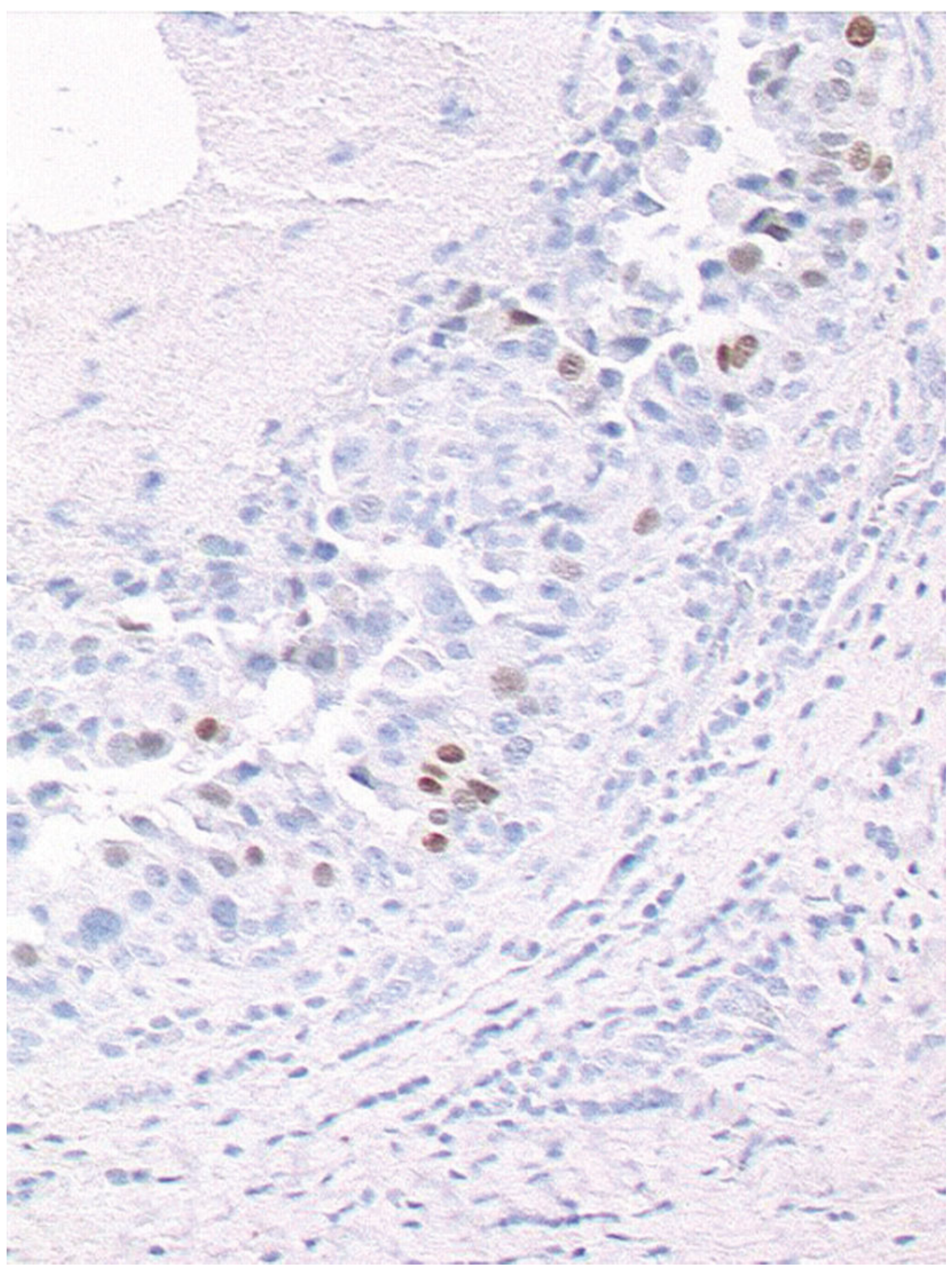

FigURE 3 - Immunohistologic detection of SSX by MAb E3AS in an invasive ductal carcinoma of the breast. Positive cancer cells show nuclear reactivity and appear scattered in different regions of the tumor. Immunoperoxidase stain, DAB; $\times 200$ magnification. 


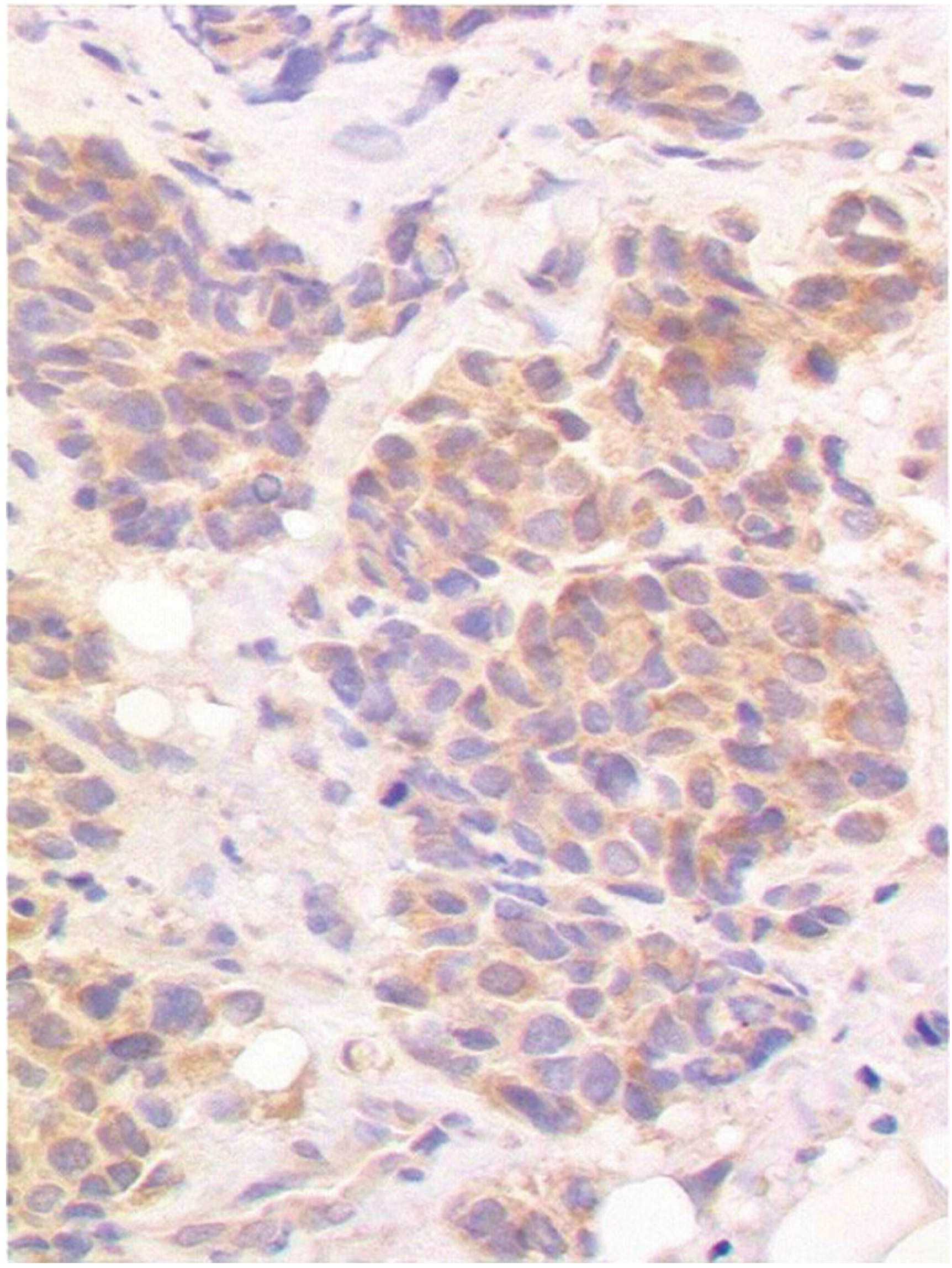

Figure 4 - Immunohistologic detection of SCP-1 by MAb SC554 in an invasive ductal carcinoma of the breast. Positive cancer cells show cytoplasmic reactivity in $20-50 \%$ of tumor cells. Immunoperoxidase stain, DAB; $\times 400$ magnification. 
was infrequent. Results concerning their expression have not been published to date for breast cancer. $S C P-1$ has also been reported by others to be the most frequently expressed $\mathrm{CT}$ antigen in breast carcinomas. ${ }^{20}$ Expression of the MAGE antigens in our study was in a range similar to what has been described in another study restricted to analysis of MAGE antigens, ${ }^{34}$ while it was reported to be higher in poorly differentiated breast cancers. ${ }^{35}$

Reports on the association of CT gene expression with clinical parameters must be met with caution because the associations are usually weak and the significance levels not adjusted for multiple testing. This also applies to the reported correlation of NY-ESO-I $\mathrm{T}$-cell responses with antibody responses, ${ }^{36}$ which could not be confirmed by others. ${ }^{37}$ In another study, NY-ESO-I was associated with higher histologic grade $(p=0.097)$ and negative estrogen receptor status $(p=0.082)$. MAGE immunoreactivity was inversely correlated with tumor differentiation in yet another study. ${ }^{35}$ In our study, we observed trends $(p<0.05)$ for an association between $N Y$-ESO- 1 and lobular rather than ductal carcinoma, $M A G E-3$ and large primary tumors $(\mathrm{T} 3,4)$ as well as higher histologic grade and $S C P-1$ and the absence of estrogen receptors in the tumor and nodular involvement; however, after adjusting for multiple testing, these correlations failed to reach the adjusted significance level of $p<0.0083$ (i.e., $p<0.05 / \mathrm{G}=0.083$ for testing 6 clinical parameters). Even if the prognostic subgroups of patients in Table I were large enough to yield statistically significant differences, the figures in Table I make it clear that such differences would be in the range of a few percent only.

Whether immunologic factors play a role in the pathogenesis of human breast cancer is still a matter of debate. Lymphoid infiltrates are frequent in breast cancer, ${ }^{38-40}$ particularly the intense Band T-cell infiltrates in medullary carcinoma, ${ }^{41,42}$ and suggest that there is immune recognition in breast cancer; however, there is as yet no conclusive evidence that such infiltrates have prognostic value. ${ }^{43}$ From our data, it becomes evident that $90 \%$ of our patients with primary breast carcinoma would be eligible for specific immunotherapeutic approaches with at least one CT antigen, nearly two-thirds would be eligible for a bivalent CT antigen vaccin, and for nearly half a trivalent vaccine would be available. This makes primary breast cancer one of the human neoplasms with the most frequent expression of CT genes. Several phase I studies using various vaccine strategies similar to those previously evaluated in malignant melanomas ${ }^{44-46}$ have suggested the safety of this approach in breast cancer patients ${ }^{47}$ and other types of human cancer. ${ }^{48}$ As a note of caution, however, one should keep in mind that SCP-1 and SSX expression at the protein level could be demonstrated not in all cases expressing the respective mRNA. Whether this is due to a lower sensitivity of the detection method used (immunohistology using CT antigen-specific antibodies) or whether the mRNA is not translated into protein cannot be determined at this point. The fact that we detected $S C P-1$ antibodies in patients with $S C P-1$ mRNA-positive tumors that were negative on immunohistology suggests that the failure to detect the antigenic protein is rather due to sensitivity problems of the immunohistologic method. It also shows that mRNA-positive tumors can elicit immune responses even if the specific protein expression is below the immunohistologic detection level. However, even if small amounts of protein can elicit specific IgG antibody responses in a cancer patient, it remains to be shown whether antigen expression that is below the detection limit by immunohistology can render a tumor cell a target of a successful cytotoxic immune attack. Our study shows that the demonstration of expression of cancer-specific antigens by tumor cells is only an important first step on the long road to the development of a clinically successful vaccine for breast cancer.

\section{References}

1. Greenlee RT, Murray T, Bolden S, Wingo PA. Cancer statistics, 2000. CA Cancer J Clin 2000;50:7-33.

2. Goldhirsch A, Wood WC, Gelber RD, Coates AS, Thurlimann B, Senn HJ. Meeting highlights: updated international expert consensus on the primary therapy of early breast cancer. J Clin Oncol 2003;21: 3357-65.

3. Kaufmann M, Bajetta E, Dirix LY, Fein LE, Jones SE, Zilembo N, Dugardyn JL, Nasurdi C, Mennel RG, Cervek J, Fowst C, Polli A, et al. Exemestane is superior to megestrol acetate after tamoxifen failure in postmenopausal women with advanced breast cancer: results of a phase III randomized double-blind trial. The Exemestane Study Group. J Clin Oncol 2000;18:1399-411.

4. Bishop JF, Dewar J, Toner GC, Smith J, Tattersall MH, Olver IN, Ackland S, Kennedy I, Goldstein D, Gurney H, Walpole E, Levi J, et al. Initial paclitaxel improves outcome compared with CMFP combination chemotherapy as front-line therapy in untreated metastatic breast cancer. J Clin Oncol 1999;17:2355-64.

5. Slamon DJ, Leyland-Jones B, Shak S, Fuchs H, Paton V, Bajamonde A, Fleming T, Eiermann W, Wolter J, Pegram M, Baselga J, Norton L. Use of chemotherapy plus a monoclonal antibody against HER2 for metastatic breast cancer that overexpresses HER2. N Engl J Med 2001;344:783-92.

6. Seregni E, Coli A, Mazzucca N. Circulating tumour markers in breast cancer. Eur J Nucl Med Mol Imaging 2004;31(Suppl 1):S15-22.

7. Rentzsch C, Kayser S, Stumm S, Watermann I, Walter S, Stevanovic S, Wallwiener D, Guckel B. Evaluation of pre-existent immunity in patients with primary breast cancer: molecular and cellular assays to quantify antigen-specific $\mathrm{T}$ lymphocytes in peripheral blood mononuclear cells. Clin Cancer Res 2003;9:4376-86.

8. Chen YT, Scanlan MJ, Sahin U, Tureci O, Gure AO, Tsang S, Williamson B, Stockert E, Pfreundschuh M, Old LJ. A testicular antigen aberrantly expressed in human cancers detected by autologous antibody screening. Proc Natl Acad Sci USA 1997;94:1914-18.

9. De Smet C, Lurquin C, Lethe B, Martelange V, Boon T. DNA methylation is the primary silencing mechanism for a set of germ line- and tumor-specific genes with a CpG-rich promoter. Mol Cell Biol 1999; 19:7327-35.

10. van der Bruggen $P$, Traversari C, Chomez P, Lurquin C, De Plaen E, Van den EB, Knuth A, Boon T. A gene encoding an antigen recognized by cytolytic $\mathrm{T}$ lymphocytes on a human melanoma. Science $1991 ; 254: 1643-7$.
11. Boel P, Wildmann C, Sensi ML, Brasseur R, Renauld JC, Coulie P, Boon T, van der BP. BAGE: a new gene encoding an antigen recognized on human melanomas by cytolytic $\mathrm{T}$ lymphocytes. Immunity 1995;2:167-75.

12. Van den Eynde B, Peeters O, De Backer O, Gaugler B, Lucas S, Boon T. A new family of genes coding for an antigen recognized by autologous cytolytic T lymphocytes on a human melanoma. J Exp Med 1995; 182:689-98.

13. Tureci O, Sahin U, Schobert I, Koslowski M, Scmitt H, Schild HJ Stenner F, Seitz G, Rammensee HG, Pfreundschuh M. The SSX-2 gene, which is involved in the $\mathrm{t}(\mathrm{X} ; 18)$ translocation of synovial sarcomas, codes for the human tumor antigen HOM-MEL-40. Cancer Res 1996;56:4766-72

14. Gure AO, Wei IJ, Old LJ, Chen YT. The SSX gene family: characterization of 9 complete genes. Int J Cancer 2002;101:448-53.

15. Tureci O, Sahin U, Zwick C, Koslowski M, Seitz G, Pfreundschuh M. Identification of a meiosis-specific protein as a member of the class of cancer/testis antigens. Proc Natl Acad Sci USA 1998;95:521116.

16. Chen YT, Gure AO, Tsang S, Stockert E, Jager E, Knuth A, Old LJ. Identification of multiple cancer/testis antigens by allogeneic antibody screening of a melanoma cell line library. Proc Natl Acad Sci USA 1998;95:6919-23.

17. Tureci O, Sahin U, Koslowski M, Buss B, Bell C, Ballweber P, Zwick C, Eberle T, Zuber M, Villena-Heinsen C, Seitz G, Pfreundschuh M. A novel tumour associated leucine zipper protein targeting to sites of gene transcription and splicing. Oncogene 2002;21:3879-88.

18. Sahin U, Tureci O, Schmitt H, Cochlovius B, Johannes T, Schmits R, Stenner F, Luo G, Schobert I, Pfreundschuh M. Human neoplasms elicit multiple specific immune responses in the autologous host. Proc Natl Acad Sci USA 1995;92:11810-13.

19. Russo V, Traversari C, Verrecchia A, Mottolese M, Natali PG, Bordignon C. Expression of the MAGE gene family in primary and metastatic human breast cancer: implications for tumor antigen-specific immunotherapy. Int J Cancer 1995;64:216-21.

20. Mashino K, Sadanaga N, Tanaka F, Yamaguchi H, Nagashima H, Inoue $\mathrm{H}$, Sugimachi K, Mori M. Expression of multiple cancer-testis antigen genes in gastrointestinal and breast carcinomas. Br J Cancer 2001;85:713-20.

21. Sobin LH Wittekind Ch. TNM classification of malignant tumours, 6th ed. 2002. New York: Wiley-Liss. 
22. Tureci O, Chen YT, Sahin U, Gure AO, Zwick C, Villena C, Tsang S, Seitz G, Old LJ, Pfreundschuh M. Expression of SSX genes in human tumors. Int J Cancer 1998;77:19-23.

23. Kubuschok B, Xie X, Jesnowski R, Preuss KD, Romeike BF, Neumann F, Regitz E, Pistorius G, Schilling M, Scheunemann P, Izbicki JR, Lohr JM, Pfreundschuh M. Expression of cancer testis antigens in pancreatic carcinoma cell lines, pancreatic adenocarcinoma and chronic pancreatitis. Int J Cancer 2004;109:568-75.

24. Luo G, Huang S, Xie X, Stockert E, Chen YT, Kubuschok B, Pfreundschuh M. Expression of cancer-testis genes in human hepatocellular carcinomas. Cancer Immun 2002;2:11.

25. Mischo A, Wadle A, Watzig K, Jager D, Stockert E, Santiago D, Ritter G, Regitz E, Jager E, Knuth A, Old L, Pfreundschuh M, Renner C. Recombinant antigen expression on yeast surface (RAYS) for the detection of serological immune responses in cancer patients. Cancer Immun 2003;3:5.

26. Sahin U, Koslowski M, Tureci O, Eberle T, Zwick C, Romeike B Moringlane JR, Schwechheimer K, Feiden W, Pfreundschuh M. Expression of cancer testis genes in human brain tumors. Clin Cancer Res 2000;6:3916-22.

27. dos Santos NR, Torensma R, de Vries TJ, Schreurs MW, de Bruijn DR, Kater-Baats E, Ruiter DJ, Adema GJ, van Muijen GN, van Kessel AG. Heterogeneous expression of the SSX cancer/testis antigens in human melanoma lesions and cell lines. Cancer Res 2000;60:1654 62.

28. Sahin U, Tureci O, Chen YT, Seitz G, Villena-Heinsen C, Old LJ, Pfreundschuh M. Expression of multiple cancer/testis (CT) antigens in breast cancer and melanoma: basis for polyvalent CT vaccine strategies. Int J Cancer 1998;78:387-9.

29. Sugita Y, Wada H, Fujita S, Nakata T, Sato S, Noguchi Y, Jungbluth AA, Yamaguchi M, Chen YT, Stockert E, Gnjatic S, Williamson B, et al. NY-ESO-1 expression and immunogenicity in malignant and benign breast tumors. Cancer Res 2004;64:2199-204.

30. Old LJ. Cancer/testis (CT) antigens-a new link between gametogenesis and cancer. Cancer Immun 2001;1:1

31. Zendman AJ, Ruiter DJ, van Muijen GN. Cancer/testis-associated genes: identification, expression profile, and putative function. J Cell Physiol 2003;194:272-88.

32. Heyting C. Synaptonemal complexes: structure and function. Curr Opin Cell Biol 1996;8:389-96.

33. Xie X, Wacker HH, Huang S, Regitz E, Preuss KD, Romeike B, Parwaresch R, Tiemann M, Pfreundschuh M. Differential expression of cancer testis genes in histological subtypes of non-Hodgkin's lymphomas. Clin Cancer Res 2003;9:167-73.

34. Otte M, Zafrakas M, Riethdorf L, Pichlmeier U, Loning T, Janicke F, Pantel K. MAGE-A gene expression pattern in primary breast cancer. Cancer Res 2001;61:6682-7.

35. Kavalar R, Sarcevic B, Spagnoli GC, Separovic V, Samija M, Terracciano L, Heberer M, Juretic A. Expression of MAGE tumour-associated antigens is inversely correlated with tumour differentiation in invasive ductal breast cancers: an immunohistochemical study. Virchows Arch 2001;439:127-31.
36. Jager E, Gnjatic S, Nagata Y, Stockert E, Jager D, Karbach J, Neumann A, Rieckenberg J, Chen YT, Ritter G, Hoffman E, Arand M, et al. Induction of primary NY-ESO-1 immunity: $\mathrm{CD}^{+}{ }^{+} \mathrm{T}$ lymphocyte and antibody responses in peptide-vaccinated patients with NYESO- ${ }^{+}$cancers. Proc Natl Acad Sci USA 2000;97:12198-203.

37. Neumann F, Wagner C, Kubuschok B, Stevanovic S, Rammensee $\mathrm{HG}$, Pfreundschuh M. Identification of an antigenic peptide derived from the cancer-testis antigen NY-ESO-1 binding to a broad range of HLA-DR subtypes. Cancer Immunol Immunother 2004;53:589-99.

38. Giorno R. Mononuclear cells in malignant and benign human breast tissue. Arch Pathol Lab Med 1983;107:415-17.

39. Bhan AK, DesMarais CL. Immunohistologic characterization of major histocompatibility antigens and inflammatory cellular infiltrate in human breast cancer. J Natl Cancer Inst 1983;71:507-16.

40. Hurlimann J, Saraga P. Mononuclear cells infiltrating human mammary carcinomas: immunohistochemical analysis with monoclonal antibodies. Int J Cancer 1985;35:753-62.

41. Ben Ezra J, Sheibani K. Antigenic phenotype of the lymphocytic component of medullary carcinoma of the breast. Cancer 1987 59:2037-41.

42. Gaffey MJ, Frierson HF Jr, Mills SE, Boyd JC, Zarbo RJ, Simpson JF, Gross LK, Weiss LM. Medullary carcinoma of the breast. Identification of lymphocyte subpopulations and their significance. Mod Pathol 1993;6:721-8.

43. Fisher ER, Costantino J, Fisher B, Redmond C. Pathologic findings from the National Surgical Adjuvant Breast Project (protocol 4). Discriminants for 15-year survival. National Surgical Adjuvant Breast and Bowel Project Investigators. Cancer 1993;71:2141-50.

44. Marchand M, van Baren N, Weynants P, Brichard V, Dreno B, Tessier MH, Rankin E, Parmiani G, Arienti F, Humblet Y, Bourlond A, Vanwijck R, et al. Tumor regressions observed in patients with metastatic melanoma treated with an antigenic peptide encoded by gene MAGE-3 and presented by HLA- A1. Int J Cancer 1999;80:219-30.

45. Nestle FO, Alijagic S, Gilliet M, Sun Y, Grabbe S, Dummer R, Burg G, Schadendorf D. Vaccination of melanoma patients with peptide- or tumor lysate-pulsed dendritic cells. Nat Med 1998;4:328-32.

46. Rosenberg SA, Yang JC, Schwartzentruber DJ, Hwu P, Marincola FM, Topalian SL, Restifo NP, Dudley ME, Schwarz SL, Spiess PJ, Wunderlich JR, Parkhurst MR, et al. Immunologic and therapeutic evaluation of a synthetic peptide vaccine for the treatment of patients with metastatic melanoma. Nat Med 1998;4:321-7.

47. Davis ID, Chen W, Jackson H, Parente P, Shackleton M, Hopkins W, Chen Q, Dimopoulos N, Luke T, Murphy R, Scott AM, Maraskovsky E, et al. Recombinant NY-ESO-1 protein with ISCOMATRIX adjuvant induces broad integrated antibody and $\mathrm{CD} 4^{+}$and $\mathrm{CD}^{+} \mathrm{T}$ cell responses in humans. Proc Natl Acad Sci USA 2004;101:10697-702.

48. Gjertsen MK, Buanes T, Rosseland AR, Bakka A, Gladhaug I, Soreide O, Eriksen JA, Moller M, Baksaas I, Lothe RA, Saeterdal I, Gaudernack G. Intradermal ras peptide vaccination with granulocytemacrophage colony-stimulating factor as adjuvant: clinical and immunological responses in patients with pancreatic adenocarcinoma. Int J Cancer 2001;92:441-50. 